\title{
CHANGES IN CHEMICAL COMPONENTS OF LEAF LITTER OF GINKGO BILOBA DURING MULCHING
}

\author{
by Zhenfu Jin', Byung Yeoup Chung', Kenji liyama², and Satomi Watanabe ${ }^{3}$
}

\begin{abstract}
The biological decomposition and chemical changes of leaf litter of Ginkgo biloba both at the surface and bottom layers were studied for 1 year. The changes in components such as the yields of $80 \%$ ethanol and water extractives, neutral sugars, uronic acids, Klason residues, acid-soluble phenolics, ash, nitrogen, and carbon were investigated. There were great drops of the yields of $80 \%$ ethanol extractives and water extractives in both surface and bottom mulch layers. Klason residues and sugars were the major components of the solid residues. The Klason residues lost $2.2 \%$ and $30.5 \%$ of their initial mass at the surface and bottom layers, respectively, during mulching. The total losses of the neutral sugars were $71.6 \%$ at the surface layer and $89.3 \%$ at the bottom layer. These results implied that the Klason residues were the most important inner component restraining the decomposition of the leaf litter of G. biloba and all analyzed cell wall components at the bottom layer had faster decomposition rates than those at the surface layer. Nitrogen content increased during one year of mulching, while changes in carbon contents were less than $1 \%$ throughout experiment.

Key Words. Ginkgo biloba; mulching; mass loss; leaf litter decomposition.
\end{abstract}

Environmental concern about global warming, urban heat islands, and air pollution has brought attention to the potential of trees to ameliorate climate and conserve energy (McPherson and Rowntree 1993). Trees contribute greatly to the quality of life in larger metropolitan areas, where they have become a valuable component of municipal infrastructure. But urban forests need maintenance, and maintenance activities generate a great deal of limbs, leaves, and grass clippings that historically have been considered waste. According to the United States inventory, urban tree residues are estimated to account for approximately $18 \%$ of municipal solid waste and are the second largest contributor to the U.S. municipal solid waste load (Whittier et al. 1995). Waste is typically burned or landfilled. Recycling urban forest waste can help relieve much of the pressure on overcrowded municipal landfills, improve the urban environment, and benefit carbon fixation.
Ginkgo biloba L. is used principally as a street tree species and for other ornamental plantings (Doran 1954). G. biloba also is one of the most common trees in Japan (Handa et al. 1997). Many studies on leaf litter decomposition have been conducted in the forest ecosystem. Approximately 1,000 papers dealing directly with litter decomposition have been published since 1980 (Heal et al. 1997). However, information on leaf litter decomposition in urban areas is limited.

The objective of our study was to investigate litter decomposition and to ascertain changes in chemical composition of leaf litter of G. biloba during 1 year of mulching.

\section{MATERIAL AND METHODS Mulching of Leaf Litter}

The mulching experiment was conducted at the experimental field (latitude $35^{\circ} 41^{\prime} \mathrm{N}$; longitude $139^{\circ} 46^{\prime} \mathrm{E}$ ) of the University of Tokyo. Fallen leaves of G. biloba were collected from the campus of the University of Tokyo in early winter 1999 and placed in bags. Bags $[20 \times 20 \mathrm{~cm}$ $(7.9 \times 7.9$ in. $)]$ were made of nylon net with a mesh size of $0.1 \mathrm{~mm}$ (0.003 in.). Leaf litter [ $50 \mathrm{~g}(1.8 \mathrm{oz})$ dry weight] were packed in a bag, and 20 bags were placed on soil (the bottom layer), and covered by leaf litter of G. biloba with 15-cm (6-in.) thickness. Another 20 bags were placed at the surface layer of mulches. Litter bags were recovered from both the bottom and surface layers at 2-month intervals for 1 year.

\section{Determination of Decomposition Rate}

Foreign material was removed from the bagged leaf litter. The litter was dried for 3 days at room temperature and then weighed. The moisture content of each sample was determined after oven-drying overnight at $105^{\circ} \mathrm{C}$ $\left(221^{\circ} \mathrm{F}\right)$. The remaining mass in the litter bags was calculated using the following formula:

$$
\mathrm{W}_{\mathrm{RM}}=\mathrm{W} \times(1-\text { moisture content }),
$$

where $\mathrm{W}$ is the air-dried weight and $\mathrm{W}_{\mathrm{RM}}$ is the ovendried weight of remaining sample. The dry mass loss of leaf litter was calculated as follows: 


$$
\mathrm{L}(\%)=\left(\mathrm{W}_{\mathrm{o}}-\mathrm{W}_{\mathrm{m}}\right) / \mathrm{W}_{\mathrm{o}} \times 100
$$

where $\mathrm{L}$ is oven-dried weight loss, and $\mathrm{W}_{\mathrm{o}}$ and $\mathrm{W}_{\mathrm{m}}$ are oven-dried weights of the original and mulched samples, respectively. The litter decomposition rate was calculated through the negative exponential decay model of Olson (1963):

$$
\mathrm{W}_{\mathrm{t}} / \mathrm{W}_{\mathrm{o}}=\mathrm{e}^{-\mathrm{kt}} \text {, }
$$

where $\mathrm{W}_{\mathrm{t}}$ is the oven-dried weight at time $\mathrm{t}$, and $\mathrm{k}$ is the annual decomposition rate.

\section{Chemical Analysis of Leaf Litter}

Air-dried samples were ground in a Wiley mill to pass through a $420-\mu \mathrm{m}$ sieve. The ground sample was extracted three times with boiling $80 \%$ aqueous ethanol $(\mathrm{v} / \mathrm{v})$ for one hour followed by water extraction overnight at room temperature. The neutral sugars were released by hydrolysis with $4 \%$ sulfuric acid for 1 hour at $121^{\circ} \mathrm{C}\left(249.8^{\circ} \mathrm{F}\right)$ after treatment with $72 \%$ sulfuric acid for 1 hour at room temperature. The neutral sugars in the hydrolysate were analyzed as their alditol acetates (Blakeney et al. 1983) using myo-inositol as an internal standard by a Shimadzu GC-1700 gas chromatograph [TC 17 capillary column: $30 \mathrm{~m} \times 0.25 \mathrm{~cm}(98.4 \mathrm{ft} \times 0.1$ in. $)$ id., column temperature $210^{\circ} \mathrm{C}\left(410^{\circ} \mathrm{F}\right)$, carrier gas: $\left.\mathrm{He}\right]$. Uronic acid was determined colorimetrically, using glucuronic acid as the standard (Scott 1979). Klason residue was determined gravimetrically by TAPPI Standard T $222 \mathrm{om}-88$, which is the standard procedure to determine Klason lignin. The supernatant obtained after filtration of the Klason residues was conducted for determination of acid-soluble phenolics with the Shimadzu UV-3010 spectrometer using $110 \mathrm{~g}-1 . \mathrm{L} \cdot \mathrm{cm}^{-1}$ of extinction coefficient at $205 \mathrm{~nm}$ (Schöning and Johansson 1965). Aromatic composition of polyphenolic components was investigated by an alkaline nitrobenzene oxidation (Iiyama and Lam 1990). The products of an alkaline nitrobenzene oxidation were quantified as trimethylsilyl derivatives by a Shimadzu GC-18A gas chromatograph (NB-1 capillary column: $30 \mathrm{~m} \times 0.25$ $\mathrm{cm}$ id., column temperature: $150^{\circ} \mathrm{C}\left(65.5^{\circ} \mathrm{F}\right)$ for 10 minutes then programmed to $280^{\circ} \mathrm{C}\left(137.8^{\circ} \mathrm{F}\right)$ with $5^{\circ} \mathrm{C}\left(-15^{\circ} \mathrm{F}\right)$ per minute, carrier gas: He). Ethylvanillin (3ethoxy-4-hydroxybenzaldehyde) was used as an internal standard. Ash content was measured after combustion in a muffle furnace for 3 hours at $700^{\circ} \mathrm{C}\left(371.1^{\circ} \mathrm{F}\right)$. The contents of carbon and nitrogen were determined with a CHN elemental analyzer (Perkin Elmer 240). Protein contents were calculated as $\mathrm{N} \times 6.25$ (Lam et al. 1990).

\section{RESULTS AND DISCUSSION Chemical Composition of Original Leaf Litter of $\mathbf{G}$. biloba}

The total extractives made up $39.2 \%$ of dry matter of the original leaf litter. The chemical analyses of the original leaves of G. biloba revealed Klason residue and neutral sugars as dominating components (Tables 1 and 2). Polyphenolic compound was accounted as acid insoluble residue ( $37.1 \%$ based on an extract-free sample) with the Klason procedure together with the acid soluble phenolic constituent $(2.7 \%$ based on an extractfree sample). A significantly low yield of vanillin was detected in alkaline nitrobenzene oxidation products (36.2 mmol $/ \mathrm{kg}$ ), suggesting that lignin as the major component of Klason residue would be highly condensed due to localization in the vascular tissues of leaves. Glucose was clearly the predominant polysaccharide component. Most of the glucose would originate from cellulose. Of the other five neutral sugar components, arabinose was the biggest component followed by galactose. The quantities of mannose, rhamnose, and xylose $(3.1 \%, 2.8 \%$, and $2.7 \%$, respectively, based on an extract-free sample) were similar to one other. Arabinose, galactose, xylose, mannose, and glucose would have come from $O$-acetyl-galactoglucomannan and arabino4-O-methyl-glucronoxylan, which were the major cell wall noncellulosic polysaccharides in cell walls of gymnosperms. Arabinose and galactose also could originate from pectic substrates such as rhamnogalacturonan, and from water-soluble neutral polysaccharides such as arabinogalactan and galactan. Content of uronic acid of original leaves of G. biloba was $11.0 \%$ based on an extractfree sample. Protein and ash contents were $5.6 \%$ and $10.5 \%$, respectively, based on an extract-free sample.

\section{Weight Loss}

Annual decomposition rate $(\mathrm{k})$ is commonly used for studies to elucidate litter decomposition rates between species or various environments (Guo and Sims 1999). Weights of the original leaf litters were lost by $52.7 \%$ and $69.1 \%$ at the surface and bottom during mulching for 1 year, respectively (Tables 1 and 2). Annual decomposition rates calculated by the single exponential function (Olson 1963) were 0.74 and 1.30 at the surface and bottom, respectively. Leaf litter of G. biloba had a higher annual decomposition rate than those of leaf litters of Cinnamomum camphora (0.63), Firmiana simplex (0.48), and Zelkova serrata (0.36) under similar environmental conditions (unpublished data). Compositional character- 
Table 1. Changes in the relative content of components of leaf litter of Ginkgo biloba at the surface during mulching (percentage of oven-dried sample).

\begin{tabular}{|c|c|c|c|c|c|c|c|}
\hline & \multicolumn{7}{|c|}{ Dates of sampling } \\
\hline & $\overline{12 / 15 / 99}$ & $2 / 15 / 00$ & $4 / 15 / 00$ & $6 / 15 / 00$ & $8 / 15 / 00$ & $10 / 15 / 00$ & $12 / 25 / 00$ \\
\hline Months of mulching & 0 & 2 & 4 & 6 & 8 & 10 & 12 \\
\hline Weight loss & 0 & 7.5 & 14.7 & 23.9 & 46.1 & 51.7 & 52.7 \\
\hline Water extractives & 6.0 & 5.7 & 5.6 & 4.9 & 2.8 & 1.1 & 1.0 \\
\hline Total extractives & 39.2 & 31.2 & 30.9 & 24.8 & 15.7 & 10.5 & 9.8 \\
\hline Rhamnose & 1.7 & 1.6 & 1.2 & 1.1 & 1.4 & 1.2 & 1.5 \\
\hline Xylose & 1.6 & 1.7 & 1.3 & 1.1 & 1.8 & 0.8 & 0.6 \\
\hline Mannose & 1.9 & 1.8 & 1.2 & 1.2 & 0.8 & 1.1 & 1.0 \\
\hline Galactose & 2.0 & 2.1 & 1.8 & 1.6 & 1.4 & 1.1 & 0.9 \\
\hline Glucose & 9.8 & 10.2 & 8.2 & 8.8 & 8.9 & 6.4 & 6.5 \\
\hline Total neutral sugars & 19.7 & 20.0 & 16.0 & 15.0 & 15.9 & 11.5 & 11.7 \\
\hline Uronic acid & 6.7 & 7.4 & 5.3 & 4.7 & 1.6 & 1.4 & 1.5 \\
\hline Total & 99.6 & 97.9 & 94.1 & 93.5 & 94.5 & 90.5 & 94.9 \\
\hline
\end{tabular}

Table 2. Changes in the relative content of components of leaf litter of Gingko biloba at the bottom during mulching (percentage of oven-dried sample).

\begin{tabular}{|c|c|c|c|c|c|c|c|}
\hline & \multicolumn{7}{|c|}{ Dates of sampling } \\
\hline & $12 / 15 / 99$ & $2 / 15 / 00$ & $4 / 15 / 00$ & $6 / 15 / 00$ & $8 / 15 / 00$ & $10 / 15 / 00$ & $12 / 25 / 00$ \\
\hline Months of mulching & 0 & 2 & 4 & 6 & 8 & 10 & 12 \\
\hline $80 \%$ ethanol extractives & 33.2 & 31.3 & 17.7 & 8.8 & 6.3 & 4.8 & 5.5 \\
\hline Water extractives & 6.0 & 5.4 & 5.9 & 1.3 & 1.1 & 0.6 & 0.7 \\
\hline Total extractives & 39.2 & 36.7 & 23.6 & 10.1 & 7.4 & 5.4 & 6.2 \\
\hline Xylose & 1.6 & 1.5 & 0.9 & 0.9 & 0.7 & 0.9 & 0.8 \\
\hline Mannose & 1.9 & 1.6 & 1.0 & 1.1 & 1.0 & 0.9 & 0.8 \\
\hline Galactose & 2.0 & 1.3 & 0.8 & 1.3 & 0.9 & 0.9 & 0.7 \\
\hline Glucose & 9.8 & 8.0 & 7.4 & 6.8 & 6.3 & 5.5 & 3.8 \\
\hline Total neutral sugars & 19.7 & 14.7 & 11.5 & 11.7 & 10.5 & 9.1 & 6.9 \\
\hline Uronic acid & 6.7 & 4.2 & 3.6 & 0.3 & 0.3 & 0.0 & 0.0 \\
\hline Total & 99.6 & 94.9 & 89.2 & 88.1 & 90.0 & 92.3 & 93.6 \\
\hline
\end{tabular}

istic of leaf litter have been discussed as a critical factor (Melillo et al. 1982). Lignin and nonlignin polyphenolic compounds decomposed slowly, and it has been reported that the quantity of lignin in the original litter was negatively correlated with decomposition rate (Meentemeyer 1978; Melillo et al. 1982). On the other hand, soluble substances correlate positively (Singh et al. 1999). The highest mass loss observed in G. biloba leaf litter was due to its original chemical characteristics. Compared to leaf litters of C. camphora, F simplex, and Z. serrata, G. biloba leaf litter was characterized by low Klason residues and a high content of extractives. The annual decomposition rate of G. biloba leaf litter was high compared to the values reported for other temperate ecosystems. Salamanca et al. (1998) reported that the annual decomposition rate of Quercus serrata leaf litter at the University Forest of 
Shimane University at Mt. Sanbe, Shimane Prefecture, Japan, was 0.32. Melillo et al. (1982) also reported that the annual decomposition rate of leaf litter for six species of temperate woody angiosperms ranged from 0.08 to 0.47 .

The decomposition rate of the bottom layer was characterized as very fast during the initial stage of mulching, which probably was caused by the high humidity of the bottom layer. This result was similar to the results by Singh et al. (1999). They reported that humidity and rainfall were good predictors of mass loss-much more effective than air temperature. At the surface layer, rapid mass loss occurred during the period June to August, which is the rainy season in Tokyo (Figure 1). The high decomposition rate during the rainy season reflected the favorable effect of rainfall on decomposition of leaf litter. Sundarapandian and Swamy (1999) also reported higher mass loss during the rainy season than during the dry season.

\section{Extractives}

The total yields of extractives decreased from $39.2 \%$ to $9.8 \%$ and $5.4 \%$ at the surface and the bottom, respectively (Tables 1 and 2). Extractives with 80\% ethanol decreased from $33.2 \%$ to $8.8 \%$ and $5.5 \%$, and water extractives decreased from $6.0 \%$ to $1.0 \%$ and $0.7 \%$ at the surface and bottom, respectively. Some portions of the extractives were probably leached from the cell content of leaf litter, which were degraded by microbes working on leaf cell walls (Berg and Wessén 1984). The major

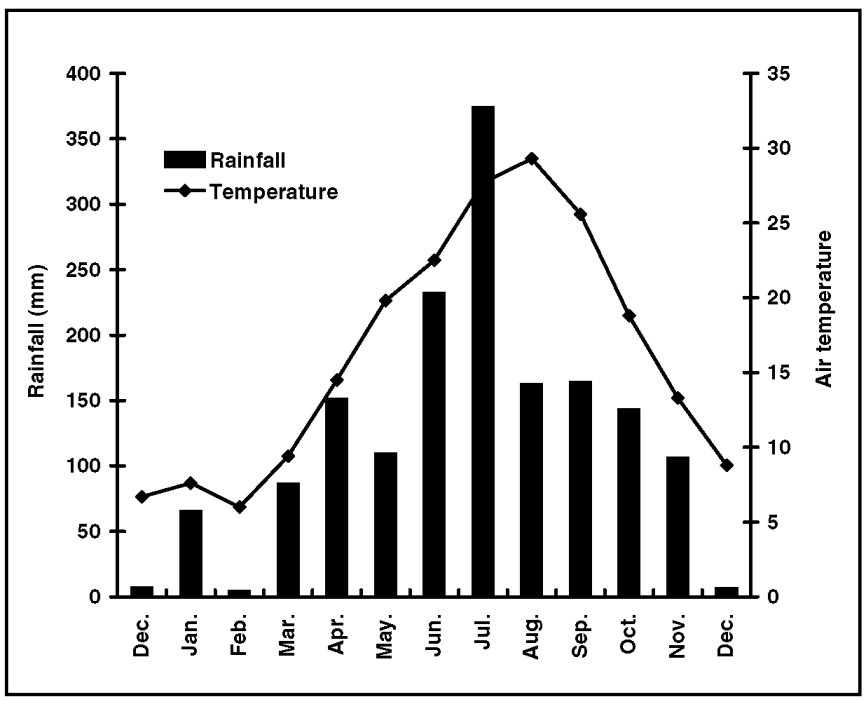

Figure 1. Rainfall and air temperature at the experimental field (latitude $35^{\circ} 41^{\prime} \mathrm{N}$; longitude $139^{\circ} 46^{\prime}$ E) of the University of Tokyo from December 1999 to December 2000. components of $80 \%$ ethanol extractives of wheat straw compost are reported to be monomeric or oligomeric carbohydrates and/or inorganic salts (Iiyama et al. 1995). In addition, both $80 \%$ ethanol and water extractives contain some of the biologically degraded and modified polymers (Iiyama et al. 1995).

\section{Solid Residues}

The solid residues slowly disappeared (Figures 2 and 3). After 1 year of mulching, weight losses were $29.8 \%$ and $52.3 \%$ at the surface and bottom, respectively. Klason residues and neutral sugars accounted for the major components of the solid residues (69.5\%) in the leaves of G. biloba. The relative amounts of Klason residues increased from $37.1 \%$ to $51.7 \%$ and $54.0 \%$ (based on solid residue) at the surface and bottom during the 1-year mulching period, respectively (Tables 1 and 2). These results were in agreement with results reported previously (Berg and Wessén 1984; Salamanca et al. 1998; Singh et al. 1999). Humic substances produced during biological decomposition are part of the Klason residue (Berg et al. 1982). The relative content of Klason residue in the solid residues increased during mulching. The acid-soluble phenolics, which made up only $2.7 \%$ of the mass of the solid residues, was almost stable during the 1 -year mulching experiment. The relative content of neutral sugars decreased from $32.4 \%$ of the original leaf litter to $13.0 \%$ and $7.4 \%$ of mulched samples for 1 year at the surface and the bottom, respectively. The glucose, which accounted for approximately one-half the mass of the neutral sugars, lost $68.4 \%$ and $89.3 \%$ of its initial mass at the surface and bottom, respectively, by mulching for 1 year. The rhamnose, arabinose, xylose, mannose, and galactose were quickly degraded (Figures 4 and 5). The uronic acid had a high mass loss rate (89.6\%) during the 1 -year mulching period, but the ash (making up $10.5 \%$ of the mass of the solid residues) had a very low mass loss rate $(3.2 \%)$.

Nitrogen content increased from $0.9 \%$ to $1.7 \%$ and $2.4 \%$ at the surface and bottom, respectively. The increase of nitrogen content in decaying leaves has been reported previously (Anderson 1973; McClaugherty et al. 1985; Melillo et al. 1982; Singh et al. 1999). Most of the nitrogen in the extracted residues would be protein, which could not be extracted due to the formation of complexes with lignin. Even if protein is easily digested by microorganisms, the results would be the same because nitrogen would be transformed into microorganisms and detected as nitrogen in mulched samples. 


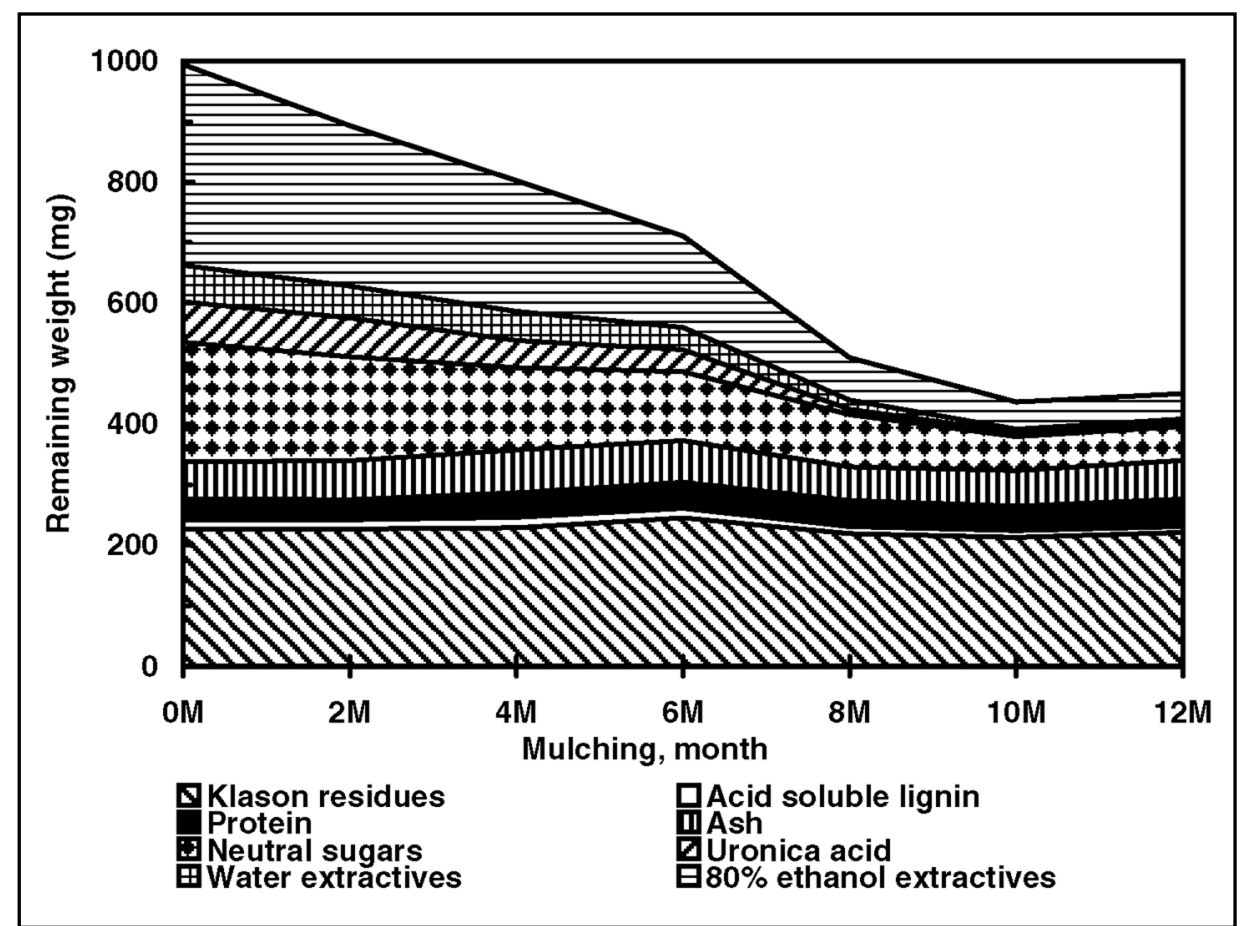

Figure 2. Reduction of the absolute amount of each component of leaf litter of Ginkgo biloba during mulching (surface layer).

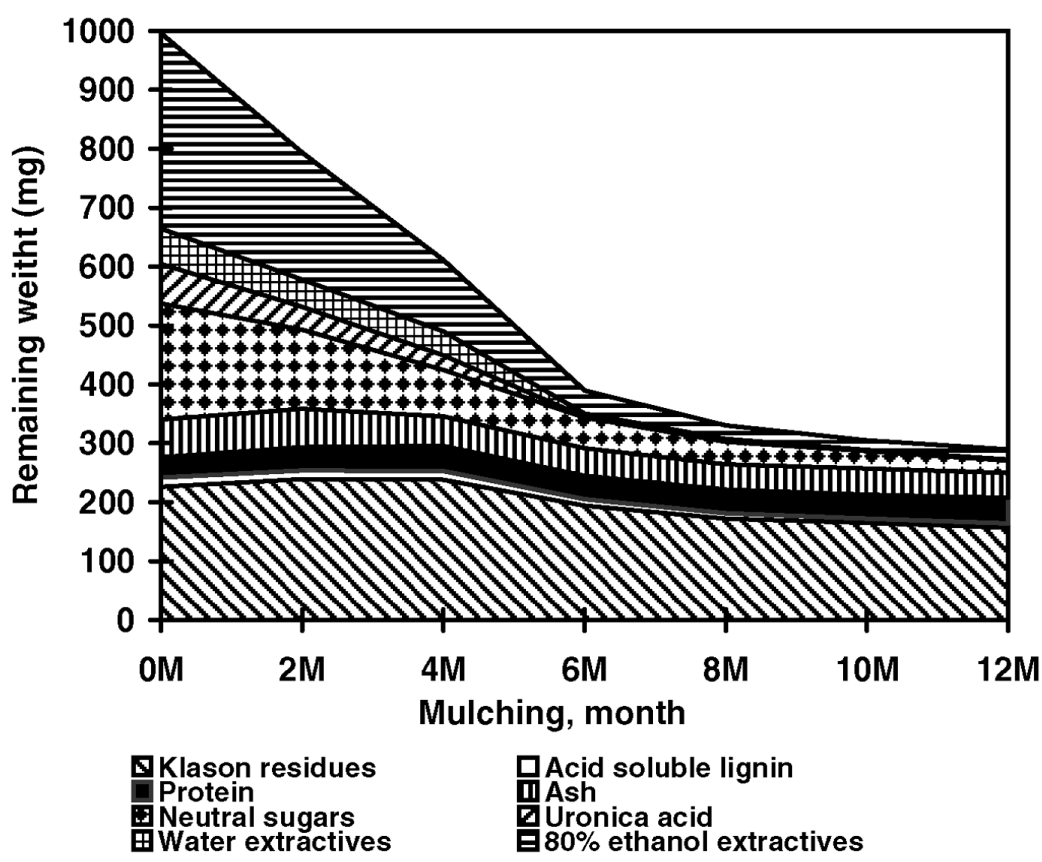

Figure 3. Reduction of the absolute amount of each component of leaf litter of Ginkgo biloba during mulching (bottom layer).
Changes in carbon content based on the residue were less than $1 \%$ throughout experiment, suggesting that the carbon content of biopolymer is significantly constant from $46.2 \%$ to $45.2 \%$. Because carbohydrate (C: $44 \%$ to $45 \%$ ) was degraded and lignin (C: $61 \%)$ was concentrated, the relative content of carbon in the residue should have increased.

\section{CONCLUSIONS}

The annual decomposition rate of G. biloba was relatively high compared to that of other species. Cell-wall components at the bottom layer of mulch decomposed faster than those at the surface layer. Extractives, uronic acid, and neutral sugars decomposed quickly and lost a considerable part of their initial mass during 1-year mulching period. The relative content of Klason residues and nitrogen increased during mulching, indicating that Klason residues and nitrogen originate from components highly resistant to degradation.

\section{LITERATURE CITED}

Anderson, J.M. 1973. The breakdown and decomposition of sweet chestnut (Castanea sativa Mill.) and beech (Fagus sylvatica L.) leaf litter in two deciduous woodland soils, I. Breakdown, leaching and decomposition. Oecologia (Berl.) 12: 251-274.

Berg, B., K. Hannus, T. Popoff, and O. Theander. 1982. Changes in organic chemical components of needle litter during decomposition: Longterm decomposition in a Scots pine forest, I. Can. J. Bot. 60:1310-1319.

Berg, B., and B. Wessén 1984. Changes in organic-chemical components and ingrowth of fungal mycelium in decomposing birch leaf litter as compared to pine needles. Pedobiologia 26:285-298. 


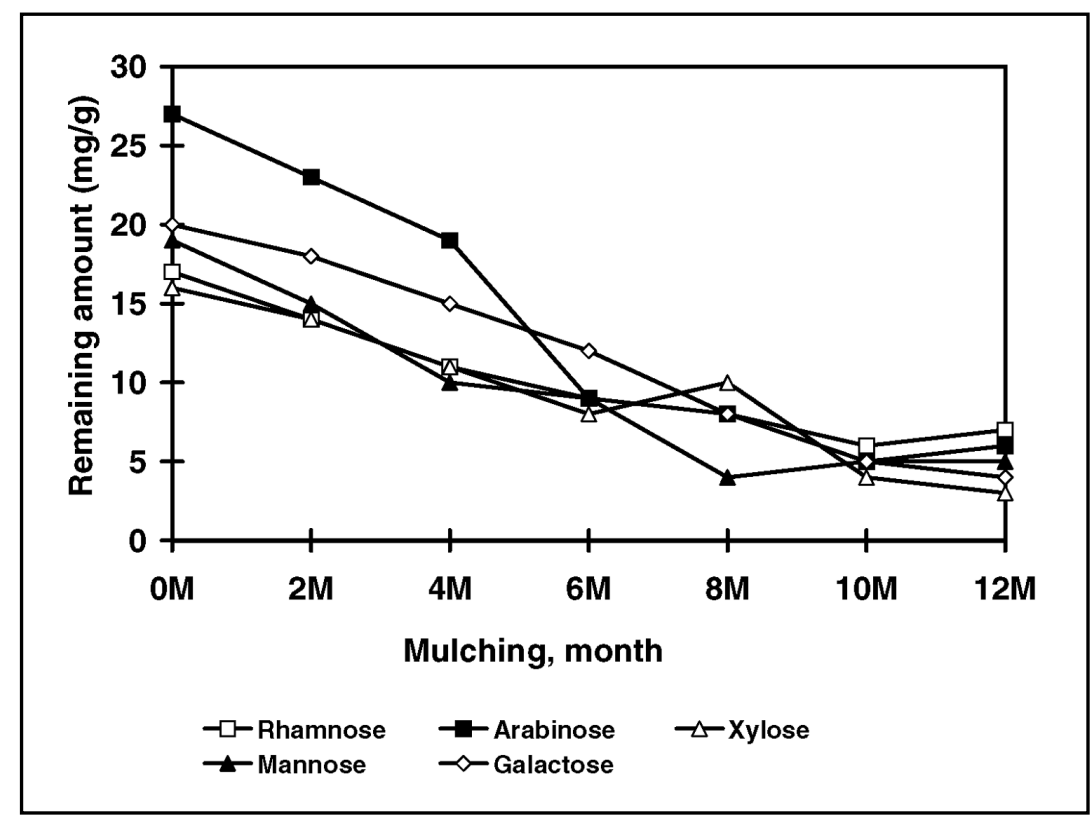

Figure 4. Decomposition of neutral sugars of leaf litter of Ginkgo biloba during mulching (surface layer).

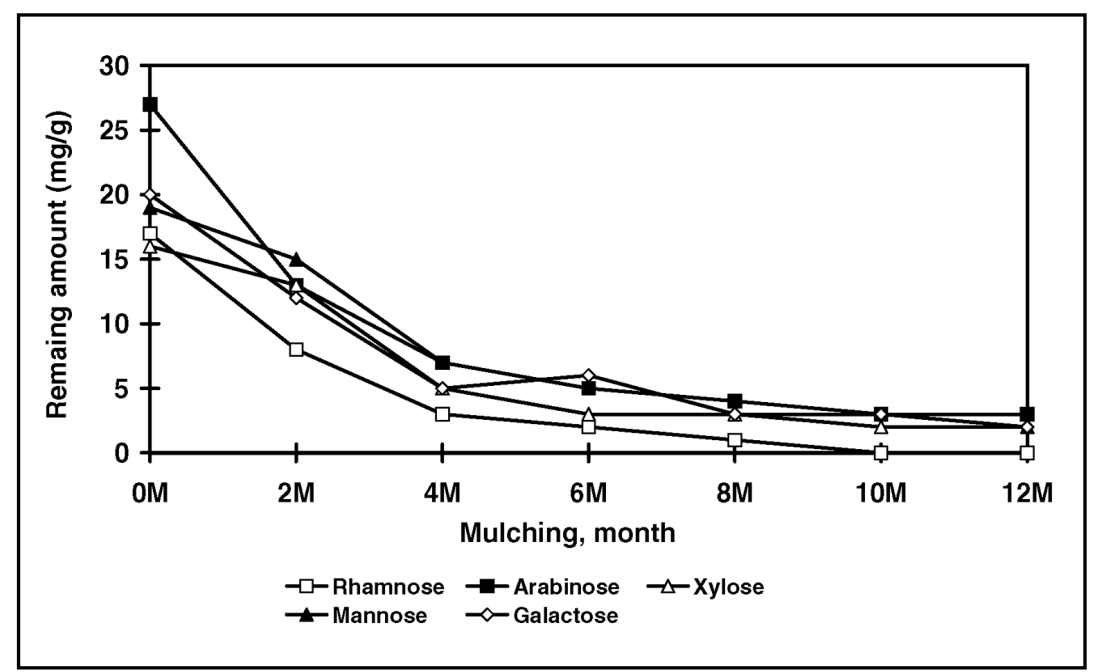

Figure 5. Decomposition of neutral sugars of leaf litter of Ginkgo biloba during mulching (bottom layer).

Blakeney, A.B., P.J. Harris, R.J. Henry, and B.A. Stone. 1983. A simple and rapid preparation of alditol acetates for monosaccharide analysis. Carbohydr. Res. 113:291-299.

Doran, W.I. 1954. The vegetative propagation of ginkgo. J. For. 52:176-177.

Guo, L.B., and R.E.H. Sims. 1999. Litter decomposition and nutrient release via litter decomposition in New Zealand eucalypt short rotation forests. Agric. Ecol. Environ. 75:133140.

Handa, M., Y. Iizuka, and N. Fujiwara. 1997. Ginkgo landscapes. J. Plant Res. (Special Issue):257-283.
Heal, O.W., J.M. Anderson, and M.J. Swift. 1997. Plant litter quality and decomposition: An historical overview, pp 3-30. In Cadisch, G., and Giller, K. E. (Eds.). Driven by Nature: Plant Litter Quality and Decomposition. CAB International, Wallingford, UK.

Iiyama, K., and T.B.T. Lam. 1990. Lignin in wheat internodes, part 1 . The reactivities of lignin units during alkaline nitrobenzene oxidation. J. Sci. Food Agric. 51:481-491.

Iiyama, K., T.B.T. Lam, B.A. Stone, P.S. Perrin, and B.J. Macauley. 1995. Compositional changes in composts during various types of composting and mushroom growth. Mushroom Sci. 51:145161.

Lam, T.B.T., K. Iiyama and B.A. Stone. 1990. Lignin in wheat internodes, part 2: Alkaline nitrobenzene oxidation by wheat straw lignin and its fractions. J. Sci. Food Agric. 51:493-506.

McClaugherty, C.A., J. Pastor, J.D. Aber, and J.M. Melillo. 1985. Forest litter decomposition in relation to soil nitrogen dynamics and litter quality. Ecology 66(1):266-275.

McPherson, E.G., and R.A. Rowntree. 1993. Energy conservation potential of urban tree planting. J.Arboric. 19(6):321-331.

Meentemeyer, V. 1978. Macroclimate and lignin control of litter decomposition rates. Ecology 59(3):465-472.

Melillo, J.M., J.D. Aber, and J.F. Muratore. 1982. Nitrogen and lignin control of hardwood leaf litter decomposition dynamics. Ecology 63(3):621-626.

Olson, J.S. 1963. Energy storage and the balance of producers and decomposers in ecological systems. Ecology 44(2):322-331.

Salamanca, E.F., N. Kaneko, S. Katagiri, and Y. Nagayama. 1998. Nutrient dynamics and lignocellulose degradation in decomposing Quercus serrata leaf litter. Ecol. Res. 13:199-210. Schöning, A.G., and G. Johansson. 1965. Absorptiometric determination of acid-soluble lignin in semichemical bisulfite pulps and in some woods and plants. Svensk Papperstidn. 68: 607-613.

Scott, R.W. 1979. Colorimetric determination of hexuronic acids in plant materials. Anal. Chem. 51(7):936-941.

Singh, K.P., P.K. Singh, and S.K. Tripathi. 1999. Litter fall, litter decomposition and nutrient release patterns in four native tree species raised on coal mine spoil at Singrauli, India. Biol. Fertil. Soils 29:371-378.

Sundarapandian, S.M., and P.S. Swamy. 1999. Litter production and leaf-litter decomposition of selected tree species in tropical forests at Kodayar in the Western Ghats, India. For. Ecol. Manage. 123:231-244. 
Whittier, J., D. Rue, and S. Haase. 1995. Urban tree residues: Results of the first national inventory. J.Arboric. 21(2):57-62.

${ }^{1 *}$ Graduate School of Agriculture and Life Science

${ }^{2}$ Asian Natural Environmental Science Center

${ }^{3}$ Graduate School of Frontier Science

The University of Tokyo

Yayoi 1-1-1, Bunkyo-Ku, Tokyo, 113-8657, Japan

*Corresponding author: Zhenfu Jin.

Résumé. La décomposition biologique et les transformations chimiques de la litière de feuilles du Ginkgo biloba, à la fois à la surface du sol et au niveau des couches inférieures, a été étudiée durant un an. Les changements des diverses parties comme le relâchement de $80 \%$ d'extrait d'éthanol et d'eau, de sucres neutres, d'acides uroniques, de résidus de Klason, d'acides phénoliques solubles, de cendre, d'azote et de carbone ont été étudiés. Il y avait de grandes chutes au niveau du relâchement de $80 \%$ des extraits d'éthanol et des extraits eau, tant au niveau de la surface que des couches inférieure d'humus. Les résidus de Klason et les sucres formaient les éléments majeurs au chapitre des résidus solides. Les résidus de Klason perdaient 2,2\% et 30,5\% de leur masse initiale, respectivement au niveau de la surface et des couches inférieures de sol, et ce durant leur transformation en humus. Les pertes totales en sucres neutres étaient de $71,6 \%$ à la surface et de $89,3 \%$ dans les couches inférieures. Ces résultats impliquaient que les résidus de Klason sont les éléments internes les plus important qui restreignent la décomposition de la litière foliaire du G. biloba; toutes les parois cellulaires des parties analysées indiquaient que les couches inférieures se décomposent à des taux plus rapides que la couche de surface. Le contenu en azote augmentait durant une année après la décomposition, alors que les changements en contenu de carbone variaient de moins de $1 \%$ durant l'ensemble du processus expérimental.

Zusammenfassung. Die biologische Kompostierung und chemische Veränderung von heruntergefallenem Laub von Ginkgo biloba wurde an der Ober- und Unterfläche der
Laubschicht für ein Jahr studiert. Die Veränderung in der Zusammensetzung, wie z.B. die Ergebnisse der Äthanolanteile und Wasserextraktion, neutrale Zucker, Uronsäuren, KlasonRückstände, säurelösliche Phenole, Asche, Stickstoff und Kohlenstoff wurden untersucht. Es gab einen starken Rückgang bei der Äthanol- und Wasserausbeute auf der Ober- und Unterschicht. Die Klason-Rückstände und die Zucker machen den Hauptanteil bei den festen Bestandteilen aus. Die KlasonRückstände verloren 2,2 \% und 30,5\% ihrer ursprünglichen Masse in der ober- und Unterschicht, besonders während des Mulchens. Die absoluten Verluste bei den neutralen Zuckern betrug 71,6\% an der Oberfläche und 89,3\% in der Unterschicht. Diese Ergebnisse beinhalten, dass die Klason-Rückstände die wichtigsten inneren Komponenten bei der Kompostierung von Ginkgo-Laub waren und alle analysierten Zellwandkomponenten in der unteren Blätterschicht größere Kompostierungsanteile hatten als in der Oberschicht. Der N-Gehalt stieg während eines gemulchten Jahres, während die Veränderungen im Kohlenstoffanteil weniger als $1 \%$ über den gesamten beobachteten Zeitraum betrugen.

Resumen. Se estudió durante un año la descomposición biológica y los cambios químicos del litter foliar de Ginkgo biloba, tanto en la superficie como en la capa más profunda. Se investigaron los cambios en componentes tales como los rendimientos de etanol y extractivos solubles al 80\%, azúcares neutrales, ácidos urónicos, residuos Klason, ácidos fenólicos solubles, cenizas, nitrógeno y carbono. Hubo fuertes descensos en los rendimientos de etanol y extractivos solubles al $80 \%$. Los residuos Klason y los azúcares fueron los principales componentes sólidos. Durante el mulching los residuos Klason perdieron $2.2 \%$ y $30.5 \%$ de su masa inicial en las capas superficial y profunda, respectivamente. Las pérdidas totales de azúcares fueron $71.6 \%$ en la capa superficial y $89.3 \%$ en la capa profunda. Estos resultados indican que los residuos Klason fueron los componentes internos más importantes que restringen la descomposición del litter de Ginkgo biloba; y todas las paredes celulares en la capa profunda tuvieron una descomposición más alta que en la capa superficial. El contenido de nitrógeno incrementó durante un año de mulching, mientras los cambios en los contenidos de carbono fueron menores al $1 \%$ a través del experimento. 